\title{
Kedves Olvasó!
}

Az Opus ez évi, harmadik száma tematikailag nagyon színes, ugyanakkor orientációját tekintve egyértelmúen érzékelteti, hogy az innovációs folyamatok, valamint alkalmazott jellegú kutatások egyre szorosabban kapcsolódnak a szakképzéshez. A közlemények, melyek között örvendetes módon több, az Opus-ban visszatérően publikáló kutató írása olvasható, olyan kutatási eredményeket ismertetnek, melyek közvetlenül vagy módszertani szempontból közvetve, de lényeges módon kapcsolódnak a munkaerő-fejlesztés, a tágabban vett oktatás-képzés folyamatainak megújitásához.

A Tanulmányok sorában elsőként a közelmúltban sikeresen PhD fokozatot szerzett Sós Tamás számol be legújabb kutatásairól, melynek célja az volt, hogy a regionalitás szempontjából feltárja az iskolarendszerű szakképzés kompetenciakínálatát, s az mennyire követi a munkaerőpiaci keresletet, így a képzés mennyire tud hozzájárulni a régióban lévő vállalkozások folyamatosan változó igényeihez. A szerző felhívja figyelmet az Ipar 4.0 során végbemenő gazdasági paradigmaváltásra, a tudásvezérelt innovációs társadalomra jellemző robotizáció kihívásaira, a mesterséges intelligencia fejlesztésére. Rámutat ugyanakkor arra is, hogy a mindennapi helyzetet viszont az jellemzi, hogy jól képzett, megfelelő végzettségú munkavállalókat sok esetben nehéz találni, miközben a munka világának a fiatal szakemberekkel szembeni minőségi elvárásai dinamikusan növekednek.

Ismert, hogy a vizuális tanulás témakörével periodikánk folyamatosan foglalkozik. Ezt érzékelteti Deli Eszter és Németh Gabriella írása, mely friss kutatási eredményekre hivatkozva, a vizuális retorika korunkban a mindennapi kommunikációban lényeges hatással bíró összefüggéseire, a szillogisztikus struktúrák jelentőségére hívja fel a figyelmet. Látszólag tematikai ugrásnak tűnik, ugyanakkor számos vonatkozásban is lényeges sajátosságokkal rendelkezik Gyarmathy Éva, Gyarmathy Zsófia, Szabó Zénó, Papp Anna, Kraicziné Szokoly Mária tanulmánya, mely arra hívja fel a figyelmet, hogy a megnövekedett ingergazdagság a diverzitás növekedése a képességszerkezet megváltozásához vezet. Kutatásuk a képességek fejlődésének vizsgálatára irányul, melyben a tizenévesek és felnőttek kognitív profiljának online mérésére vállalkoztak. E folyamatban gyorsan és könnyen használható, az iskolai sikerességben legfontosabb kognitív mutatókat megbízhatóan mérő, pedagógusok által is használható vizsgálati rendszert dolgoztak.

Kutatási eredményeket ismertető sajátosság érzékelhető a Munkaügyi Szemle rovatunk három tanulmányában is. Poór József, Juhász Tímea, Hazafi Zoltán, Székács Gábor, Kovács Ádám elemző írása jól érzékelteti, hogy milyen jelentős problémát jelent a fluktuáció a szervezetek életében. Sőt ma már a fluktuáció számít a humán erőforrások egyik fontos teljesítményindexének. A fluktuáció emelkedése olyan történésekre, problémákra és hibákra következtet, amelyek egy szervezet jövőbeni sikeres és effektív működését merőben gátolják.

A kutatási eredmények bemutatásának sorát Langerné Buchwald Judit és Muityi György írása folytatja, mely a munkaerő oktatási célú mobilizációjának összefüggéseit elemzi. A szerzők rámutatnak arra, hogy az oktatás nemzetközivé válásának hatására az egyes országok oktatási rendszerei globálisan versengő termékké váltak. Kutatásuk azzal foglalkozók, hogy a nyugat-magyarországi régióban az osztrák oktatás a magyar konkurenciájává vált. A tanulási céllal Ausztriába ingázó magyar tanulók száma a 2000-es évektől kezdve emelkedést mutat, jelenleg meghaladja az 1000 fót. Az ingázó diákokkal és szüleikkel készített interjúk alapján megállapítható, hogy az osztrák iskoláztatással a szülők elsődleges célja a majdani ausztriai munkavállalás biztosítása, a gyerekek munkavállalással és letelepedéssel kapcsolatos tervei pedig egyértelműen Ausztriához kötődnek. A szerzők a tanulási célú ingázás munkaerőpiaci és gazdasági hátterét, a vizsgált határmenti térségben megfigyelhető gazdasági hatásait tekintették át. 
E blokkban olvasható Stadler Katalin intézményi szintú pályakövetés módszertana az iskola rendszerű szakképzésben írása, mely a kutatás-fejlesztés tematikai keretei között a módszertan fontosságára, annak projektszerű fejlesztési lehetőségeire hívja fel a figyelmet.

Eszmélés rovatunk írásai is tükrözik az empirikus kutatások és azok eredményeinek szemléltetésének szándékát. Bacsa-Bán Anetta előző számban már közlésre került kutatási beszámolójának második része olvasható, mely a szakmai pedagógusok pálya-elhagyásának vizsgálatára több dimenzióban vállalkozott. Ez a különösen aktuális kérdés részletesebb bemutatása azért is fontos számunkra, mert a pedagógusképzés, azon belül a szakmai pedagógusképzés alapvető problémáira konkrét empirikus eredmények alapján hívja fel a figyelmet. Ehhez kapcsolódóan a korszerú intézményvezetői szemlélet kialakításához járulhat hozzá Ferencsik Andrea Ágnes írása, melynek szerzője azt állítja, hogy hasonló problémák, elakadások jelenhetnek meg a köznevelési intézményvezetésben is, mint a profitorientált üzleti szférában, illetve ezekre az elakadásokra a leadership szemlélet és a coaching módszertan gyors és hatékony megoldásokat kínál. A szerző, további kutatásokra is motiválva, kifejti, hogy érdemes volna feltárni a pedagógusi létformából fakadó speciális területeket, és kidolgozni egy pedagógus coachingot, melynek segítségével a tanári társadalom egy nagyon fontos mentőövet kaphatna szakmai problémáinak megoldásához. E rovat utolsó tanulmányában Bednárik Judit a szülői-pedagógusi attitűd és a tanulói értékelés, személyiségfejlődés összefüggésének vizsgálatát mutatja be, az iskola rendszerű szakképzésben. E téma azért is fontos, mert manapság egyre többet emlegetjük a közoktatásban, hogy milyen nagymértékben befolyásolja egy iskola sikerességét a vezető személye, a vezetés rátermettsége, kompetenciája. Érdekes az a panelvizsgálat, melynek keretében a szerző 30 szakgimnáziumi és 30 szakközépiskolai tanulót kérdezett meg a következő témákról: a vizsgált tanuló önértékelése, a vizsgált tanuló tapasztalata saját szüleinek nevelői attitűdjéről. Az esettanulmány, s a szerző felmérése hozzájárulhat ahhoz, hogy feltárjuk, mely életkorban, mely pedagógusi attitűdök hatnak leginkább pozitívan a tanulói önértékelésre, ami segítségül szolgálhat a lehető leghatékonyabb tanári kar megszervezésében, illetve a pedagógusok munkájának orientálásában.

Három állandó rovatunk tanulmányait végig tekintve a szerkesztő még inkább meggyőződéssel összegzi, hogy az elméleti és gyakorlati kutatások szemléletes keresztmetszetét sikerült e számunkban bemutatni, érzékeltetve azokat a problémákat, korszerű kutatási megközelítéseket, melyek a mai szakképzést, annak tágabb környezetét, valamint e közegben az új jelenségek vizsgálatát az olvasó számára is szemléltetik. E számunk, mely szándékolatlanul is egy implicite kutatási tematikus összeállítás, szerkesztése a nyáron zajlott, megjelenése szeptemberi. Ezért indokolt az elköszönés:

Jó olvasást, s különösen a pedagógusoknak sikeres tanévet kívánunk!

\section{Benedek András}

az Opus főszerkesztője

Budapest, 2019. szeptember 